\title{
Every Afternoon
}

National Cancer Institute

\section{Source}

National Cancer Institute. Every Afternoon. NCI Thesaurus. Code C154484.

Scheduled or occurring each afternoon. 